\title{
Pull and Push Factors of Indonesian Women Migrant Workers from Indramayu (West Java) to Work Abroad
}

\author{
Muhammad Iqbal \\ Mercu Buana University, Jakarta \\ E-mail: iqbal.ukm@gmail.com
}

Yuherina Gusman

Mercu Buana University, Jakarta

E-mail: yuherina.gusman@gmail.com

\section{Doi:10.5901/mjss.2015.v6n5s5p167}

\section{Abstract}

This study aims to determine the pull factors and the factors driving women Indramayu choose to work abroad. This study was conducted with a qualitative approach, data collection was done by interviewing stakeholders related to migration including village heads, parents, community leaders and former workers in the form of focus group discussion (FGD). These results indicate that female workers migrate for Indramayu have three (3) first driving factor is the economic factor is the main factor is the driving factor for women from Indramayu workers to work abroad. This is because the high level of poverty and the difficulty of getting jobs with adequate wages. The second is the social factor that drives Indramayu women workers to work abroad the ability to raise the social status with increasing economic capacity. In the context of a more micro to work abroad to be an attempt to equalize the social position of women for their contribution to the household economy. The position of women can be lifted by the success in the attempt at the destination. Culture is the third factor of this study indicate that migrate to the citizens of Indramayu has been entrenched and occurred for generations, especially families urge parents were the factors most encourage women migrate abroad. Perception of girls as an asset that can generate money is one factor that causes many women in Indramayu working as migrant workers abroad and cultural. Pull factor is Indramayu female workers to work abroad work abroad which tend to be lighter than in the country or at least equal to the salary of a much larger, culture-friendly destination, availability of jobs and the process is relatively quick departure. The current tendency of women migrant workers indramayu who go abroad are female single / not married, so the pull factor for them to work abroad that is an opportunity to add to the experience, learning a foreign language, a walk out of the country and often the reason want to continue their education into a whip of encouragement for them to work abroad.

Keywords: Motive, Indonesian Woman Migrant Workers, Indramayu West Java

\section{Background}

Labour migration has been social phenomenon in Indonesian society particularly to women who worked overseas as domestic workers. The longing of society to participate in labour migration dramatically increase due to various push and pull factors. West Java is one of province in Indonesia that largely contributes to labour migration with Indramayu County at the first rank. In 2012, there are 119,620 migrant workers coming from West Java which 28,524 of them are coming from Indramayu that recorded as the highest among other counties in Indonesia.

Migration is a common matter in Indramayu while the migration history has been lasted for long time. The strategic geography that positioned Indramayu in the coastal areas and in the between of traffic lane in Java Island made Indramayu as open area and facilitated the easiness for its citizen to migrate to other counties or cities moreover to other countries. The data in 2010 shown the numbers of population in Indramayu is around 1.769 .423 where 885.345 are men and 884.078 are women. In 2011 the number was lowering to 1.675 .790 with 862.846 are men and 812.944 are women. The land mass of Indramayu is around $2.040,11 \mathrm{~km} 2$ with the density of population is 821 persons $/ \mathrm{km} 2$.

In regard to migration, there are numerous factors has been found due to the push and pull factors of labour migration. The factors could be arisen from the internal of the country (push factors) whether from the external of the country (pull factors). Poverty, unemployment, nature disaster, war and culture has been the common push factors to labour migration. In Indramayu context, the interesting part of its labour migration story is the high numbers of women migration who participated to labour migration where the men population is prefer to stay in Indramayu. The side effects 
of this female labour migration is the major number of the workers become the victim of human trafficking. These female migrant workers become the object of forced labour, underage-employment and forced to be sex workers.

These phenomenons emerge the question, what is the push and pull factors for female migrant workers from Indramayu to work overseas? This research is designed to answer that question, to analyze the push and pull factors, also the motive of female migrant workers to work overseas.

\section{Objective}

This research is aimed to understand the push and pull factors of female migrant workers from Indrmayu to work overseas. This research is also will analyze the motivation and hope of those workers to work overseas and identify the channeling process. This research is expected to describe the whole process of migration and to find out the push and pull factors of female migrant workers to migrate.

\section{Literature Review}

\subsection{Push and Pull Factors of Migration}

Lee (1966) with his migration theory stated that migration happened due to the rational choices in regard to benefit factors at the destination country compare to the origin place of migrants, particularly on demography and economy aspects. The formulation of Lee's idea well known as push and full factors of migration. The push factors related to the condition at origin country such as unemployment, lower salary, poverty dan human right matters where pull factors concerned to the situation at destination countries such as the increasing of aging population, the cronically economic improvement, the need to higher workers to do 3D jobs (demeaning, difficult and dirty) and the dramatic degradation of birth rate.

According to Osaki (2003) in Safrida (2008) migration occurs because of the need to intrinsic labor demand to modern industrial society. Through dual labor market theory the migration is analysed due to the reason and willingness of people to migrate. This theory emphasised that the requirement of developed countries to labour market has indicated as the major pull factor of labor migration. Therefore, labour migration created is not only because of push factors at the origin countries but also because of the pull factors at destination countries.

Further in regard to push and pull factors of migration, Abella (2008) added that there are significance demography alterations in the developing and developed countries which lead to migration. In developed countries the aging population are increasing and the birth rate degrating to negative. Therefore the developed countries attracts the population in developing countries to fullfill the available job spaces to mantain their productivity. Despitefully, in term of the rapid growht of aging society the needed to caregiver and nurses also increasing which urged the pull factors for female migrant workers to work at overseas.

Meanwhile, for sending countries such as Indonesia have dense population with high unemploment rate including disguise unemployment, the huge gap in the salary with the same position of job, the high rate of poverty and high respect to human right that allow everyone to participate in migration become the push factors of migration. The high demand to nurse and care-giver provide bigger opportunity for female migrant worker in theses two decades to migrate, especialy for those from : Indonesia, Myanmar, Sri Lanka, Laos, Cambodia and Philipines.

The pull factors of migrations, as emphasized by Abella, are the higher propose salary with the same work load in the destination countries, and the degradation of productivity in developed countries due to the increasing of agingsociety and the declining of birth-rate is also stated by Djafar and Hisyam (2012) in their study to the pull and push factors of Indonesia migrant workers to work in Malaysia. Their study explained that the lower salary and the high unemployment rate bacome the most push factors for Indonesia migrant workers to work in Malaysia while the pull factors are: higher salary offered, numerous job demand due to the lower interest of Malaysia population to do low skilled worker. Other factor is the policy of both countries to easier the migration process, where Indonesia and Malaysia have signed the MOU for manage the labour migration from Indonesia to Malaysia.

\subsection{Psychology Motivation Theory}

Motive or motivation is crucial theory in psychology that able to overcome the reason of someone to act in their daily life. According to Koontz (1990) individual motivation depend on inner state that force, activate, actuate, direct, and canalized the behavior to gain ends. Motivation is a drive in someone and in their mind to do and to reach the objective. Motivation 
is also explained as a desire to gain success and avoid failure in life. In psychology, motivation segmented to intrinsic motivation (internal) and extrinsic motivation (external). Intrinsic motivation occurs when the activities motivate someone to act and create contentedness in doing the activities without other intervention such as status or money. In other words, intrinsic motivation occurs when someone doing their hobby or passion. Extrinsic motivation occurs when the external element related to the jobs become the force major that motivate someone to act, such as status or compensation.

A famous psychologist, Abraham Maslow, stated that basically human being have basic needed. He showed in a pyramid the five stages of those needed that well-known as Maslow Hierarchy of Needs as mentioned below: $a$. Physiology needs ( hungry, thirsty and so on); b. Safety needs (sense of security and protected, far away from the dangerous thing); c. Love and possessive needs (affiliate with others, acceptance of society, owning), d. Appreciation needs (achievement, competition and support from others), e. Self-actualization needs (cognitive needs : knowledge, understand, explorer; esthetic needs: harmonization, regularity, beauty, self-satisfactions, the consciousness of selfpotential).

In case the basic needs like food and sense of security are failure to be satisfied, the accomplishments to those needs will dominate the action of someone and the higher motive will be less significant. Human being will spend time and energy to focus to their passion on aesthetic and intellectual when the basic need has been accomplished easily. Masterpiece and erudition will not arise when the society is hardly to fulfil their need of food, protection and sense of security.

According to Herzberg (1966), there are two factors encourage human being to achieve contentedness and keep distance from un-satisfaction. The respective factors are higiene factor (extrinsic factor) and motivator factor (intrinsic factor). Higiene factor motivates someone to leave un-satisfaction included human relations, financial return, environment and other extrinsic factors. Motivator factor motivates someone to reach the contentedness included achievement, acknowledgment, successful and other intrinsic factors. Motivation theory founded by Mc Clelland (1961), emphasized that there are three important needs of human being as follow: a. Need for achievement, b. Need for afiliation, c. Need for Power.

\subsection{Migration Theory}

Migration is a global phenomenon in borderless world. Due to International Organization for Migration (IOM) and World Bank data, there are 214 millions people migrate to other countries which mean every 33 persons in this world are migrants. ILO (2008) stated that among 81 of migrants move to other countries for job. Most of those labour migrations occur in Asia and Middle east (around 25 millions) and 13,5 of them happen in South East Asia where 35\% of those are in Malaysia. Migrant workers are important par for the economic of their destination countries. There are 28 main destination countries, USA is the most attractive country for migrants where more than 42,8 million people choose to move there. One third among those 214 millions migrants migrate to : Bahrain, Brunei Darussalam, Kuwait, Qatar, South Korea, Saudi Arabia, Singapore, Malaysia and Emirates Arab.

In Asia Pacific region migrant workers have significant role to support the economic in Australia, New Zealand and Middle East. In South East Asia such as Singapore and Malaysia contribute 20\%-30\% workers to those countries in Asia Pacific region (ITUC-AP 2012).

In Indonesia, migration is also a common social phenomenon since long time ago. In Indonesia law, the citizen is called a migrant when they stay at a specific place for six months or more, and is counted as international migration if the citizen passes the political boundary among nations. The political boundary is very dynamic and depends on the global political constellation. Before World War Two there were an excessive number of Indonesians who migrated to Malaysia as labor plantation (APMM, 2003) and after World War Two a great number migrated to other countries such as Singapore, European countries, South American countries and Australia as ship crew. Enter the New Order Era under Soeharto leadership by 1966 migration held an important role for Indonesian economy. In this Era -New Order Eraunder REPELITA (Rencana Pebangunan Lima Tahun/ Five years Development Program) migration was divided into two clusters, the first one encompassed the citizen from dense population area in Indonesia to lesser population for example people from Java to Sumatera, Kalimantan, Sulawesi and Papua. The second one is international migration by sending Indonesian citizen to other countries.

By the 1970s Indonesian women migrant workers began to be sent to Middle East countries as domestic workers and the number kept rising until 1980. Indonesian International Migration was systematically handled by the government since 1975 then formed National Agency for the Placement and Protection of Indonesian Migrant Workers (Badan Nasional Penempatan dan Perlingungan Tenaga Kerja Indonesia/ BNP2TKI). Before BNP2TKI was formed, the placement of Indonesian migrant workers relied on the policies of Indonesia Government formulated in the year 1970 and 
handled by the Department of Labor, Transmigration and Cooperative.

Since 1998 the management of migrant workers is arranged by workers recruitment agency/PJTKI and until now the systems of international migration of Indonesian are still not systematized because of the high levels of corruption and nepotism practices. Indeed, PJTKI became the supplier of modern-day slavery especially for women migrant workers. Because PJKTI are the first line on exporting workers and has become the center of overcharging toward migrant workers using various modus, for example: do not provide salary for the worker during the training, establish dubious training fee, deduct the worker's salary illegally and trap them with high debt/debt bondage. Nonetheless, the numbers of Indonesian migrant workers are still increase every year, especially women migrant workers ${ }^{1}$.

\section{Research Method}

This research used qualitative approach by collecting data through in-deph interview with stakeholders and focus group discussion with former female migrant workers, family of female migrant workers, village leader and agencies. The research was held in three sub-districts and five villages with total 10 in-depht interview, 3 FGD groups (one group per one sub-district) with composition $40 \%$ women and $60 \%$ man where 1 group consist of 10 persons.

The research was conducted in 3 sub districts : Bongas, Patrol and Anjatan and 5 villages : Kertajaya, Kertamulya (Bongas Sub-district); Patrol Lor (Patrol Sub-district); Bugel and Anjatan Baru (Anjatan Sub-district). The tools used in this research were interview sheets arranged by the researchers with semi-open question that aimed to assist the informants to understand the questions and in order the informants able to provide the suitable answers. Recorder and camera were also used to document the research activities.

\section{Results}

Both local and global migration is accustomed to society in Indramayu. The mobilization of its population has begun in 1980's started with the migration of thw workers from Indramayu to Jakarta and other big cities in Indonesia. Up to now the population of Indramayu in great quantities migrate to overseas for labour migration to Saudi Arabia, Malaysia, Hong Kong and Taiwan. Data from BNP2TKI (2013) showed that Indramayu been at second rank as the highest sender migrant workers to overseas. There are 28.410 migrant workers has been migrated from Indramayu by 2013.

The majority of FGD respondents stated that they have female families who work outside Indramayu, mostly as domestic workers and follow as care-giver, nurse, shop attendant, labourer in the company. Some of those female workers also work as office staff and sex workers. In regard to international migration, although migration channel has been established in Indramayu for long time the great numbers of its population have lack knowledge to safe migration. There are excessive of them do not conceived the completeness of the document to work overseas, therefore not a few of them became the victim of human trafficking. Another problem is most of those female workers get into migration channel through broker that caused more problem such as : overcharging, miss-placement of the jobs, debts and so on.

\subsection{Push Factors}

This research categorized the push factors into three segments: economic, social and culture.

\subsubsection{Economic Factors}

Economic factor as shown from the previous study constituted the main push factor of female migrant workers in Indramayu to work overseas. In this case the push factors from economic segment are: the high rate of poverty, the hardship to find job and lower salary provided in Indramayu. Stakeholders as informant in in-depht interview stated that previously the main job of Indramayu population was to be farmers and fishermen. Recently the number of field and fish for farming and fishery are still excessive. However due to the higher salary offered in the overseas make the population decided to be migrant workers. As stated by one of informant:

Here [in Indramayu] the reason of most of people to migrate was economic factors. In Indramayu they only work as laborer and live in difficult situation. Around 1980s numbers of population started to migrate and work at other countries. - Informant In-Depht Interview, Kertajaya Village.

\footnotetext{
${ }^{1}$ From 6 million migrant workers from Indonesia, $82,8 \%$ of them are women.
} 
Yet, the recent trend of push factors female migrant workers in Indramayu to migrate is due to the economic successful of senior female migrant workers. The significance improvements of senior female migrant workers' economic and social life become the extrinsic factor for the increasing numbers of female migrant workers in Indramayu. The improvement as follow:

a) Luxurious housing owned by migrant workers emerged around Indramayu, this is become a motivation for the newly female migrant workers to work overseas to own the same or even better house;

b) The village economy significantly improved, the data from Social and Manpower Agency of Indramayu reported that the amount of remittance from migrant workers reach 1 billion rupiahs per day ${ }^{2}$. This is become a motivation for the female migrant workers to contribute to their countries.

c) Migration allowed them to save more money to be used as financial capital to established business after coming back from overseas.

However, further research to the role of migration to economic improvement of female migrant worker is needed. As stated by one of informant due to economic situation as push factor for female migrant workers in Indramayu, as follow:

Indeed, economy is the major forced for female migrant workers to work overseas in regard to the difficult situation in Indonesia and the successful of the senior migrant workers. However those indicators are not $100 \%$ correct, as shown in reality these female migrant workers continually work as migrant workers. There is an improvement to their salary but not their ability to manage money. For example, my neighbor who worked in Singapore, when she came back she built a house cost 700 million rupiahs. That is a lux, big and really good house. The design was made by her employer in Singapore. Several month after come back from Singapore, she sold her house to pay her big debt. That expensive haouse sold with price 300 million rupiahs only. This is shown that the female migrant workers have higher salary but have no higher ability to manage the money properly. - Informant, In Depht Interview, Patrol Village

\subsubsection{Social Factors}

Social factor which motivate female migrant workers from Indramayu to work overseas is to increase their social status in line with the improvement of their economic conditions. In the bigger context working overseas put women social status be equal with men where most of them contributed as bread winner to the family.

People [in Indramayu] encouraged by the success of senior migrant workers on gaining money. They willing to be success also and having better acknowledgement from the society. (Respondent FGD, Bongas)

However the great number of female migrant workers in Indramayu work overseas has negative impacts to socialorder in society. One of common impact is the loosing of mother figure in family due to the long term working contract ${ }^{3}$ and higher the separation-rate among wife and husband. Indramayu Religion Jurisdiction in 2013 stated that there are 9.300 lawsuit submission where $90 \%$ of those are separation indictment case. The separation rate in Indramayu is the highest in Indonesia. The causal factor of the high rate of separation are: economic problems, low education background, and the excessive number of female migrant workers work overseas who leave their husband in Indonesia. diantaranya adalah perkara tuntutan cerai, jumlah tertinggi di Indonesia. Adapun faktor penyebab tingginya angka perceraian tersebut disebabkan oleh masalah ekonomi, pendidikan dan banyaknya suami atau istri yang menjadi TKI di luar negeri. $80 \%$ of female migrant workers have problem with their marriage. ${ }^{4}$

The positive impact [of the migration of female workers from Indramayu is seen from the improvement of their economic life. The negative impact is because most of the workers are female, caused disaster to their marriage (Respondent FGD, Bongas)

\subsubsection{Cultural Factor}

One of the finding in this research on regard to cultural factor is shown that migration as heredity occupation in

2Data downloaded from : www.indramayukab.bps.go.id

${ }^{3}$ The period for the contract is usually 3 years, however the workers will extend the contract to the maximum allowed years. The total of the working period is arounds 10-12 years.

4 Data downloaded from: www.republika.co.id/berita/nasional/jawa-barat-nasional/1408/17/nafyt0-kasus-perceraian-di-indramayutertinggi-seindonesia 
Indramayu. Family and parent support has been the push factors for female migrant workers to work overseas. The perception of children especially female children as the asset to family as bread winner caused the increasing number of female migrant workers. It is cultural in Indramayu that female children as an expectation in family which will produce money one of them through becoming female migrant workers.

Especially for Bongas, [the reason of female migrant workers] to work overseas is to support the economy condition of their family, also in regard to the support from society to migrate for a better life. In other words, this is already the culture in Bongas. This culture has been done massively since 1980s. (Informant, Member of Region Parliament, Bongas)

Migration culture is not only formed from the society, yet deeper than it, is formed from family culture. In Indramayu, female children is a gift of nature which will work three prestige position : as fresh and young widower, Pantura singer and female migrant workers. In common Indonesia culture those occupation created negative perspective in society but not in Indramayu. Somehow, to support female children as sex worker is not a taboo in Indramayu.

The majority of [female migrant workers from Indramayu] work as domestic workers at overseas. However, significance number of them were smuggled as sex workers with or without the permission from the family. Sometime, the family sold their children to work as sex worker. Perhaps, this is only happen in Indramayu where parents worship day and night and held big sermon to pray for their children to be in demand easily. This should take special attention from religious leader and government because will lead the children to human trafficking. Beside, those cultural habits negatively contribute to social and health issues. There are significance numbers of those female migrant workers become the victim of human trafficking and come back to Indramayu with HIV virus on their body. (Informant, In Depht Interview, Doctor at local government clinic)

\subsubsection{Pull Factors}

This research formulated the pull factors for female migrant workers from Indramayu to overseas as follow: a. The increasing number of aging society in destination countries created higher demand to low skill workers; $b$. Higher salary offered with the same working load in Indonesia; c. The worker-friendly policies to facilitate the workers to work overseas; d. Better law protection in Hong Kong and Taiwan made those countries as most favourite destination countries for female migrant workers from Indonesia.

Others pull factors of migration for female migrant workers from Indramayu are the culture of destination countries which welcome and friendly to the workers, the easiness of departure process. The trend of recent female migrant workers from Indramayu is the workers who work abroad are single or younger widower with better education background, therefore the pull factors and motive to work overseas are not only economy, social and cultural factors but also for self-satisfaction. Working overseas becomes an opportunity to gain experiences, travelling, to reach better education, to experience multicultural environment, and to learn foreign languages.

In the past time Saudi Arabia become the favorite destination for the workers with reason while working there they will have a chance to perform hajj (pilgrim). Recently, Saudi Arabia no longer attracts young female migrant workers from Indramayu due to negative stereotype in regard to protection of the workers. Taiwan and Hong Kong currently more fascinating to young female migrant workers from indramayu due to higher salary offered and better law protection.

\section{Summary and Recommendation}

\subsection{Summary}

This research is along with Herzberg (1966), that stated there are two factors to push someone in activities: to reach the satisfaction and to avoid the un-satisfaction. Those two factors are hygiene factors (extrinsic) and motivator factor (intrinsic). Higiene factor motivated someone to come out from unsatisfaction included in human relation, financial return, environment and so on. While motivator factor support someone to gain satisfaction included achievement, acknowledgment, life improving and others.

Likewise in migration theory expanded by Lee (1966) that stated migration occurs due to rational action in regard to the benefits provide in destination countries. There are two main factors to migrate : push factors and pull factors. According to below analysis there are several push and pull factors of migration to female migrant workers in Indramayu. The main push factor is economy reason where the poverty and higher unemployment rate constitute the decision of 
female migrant workers from Indramayu to work overseas. The success stories of previous migrant workers to improve their economic condition also become the push factor for female migrant workers from Indramayu to work abroad. The pull factors are: the higher salary offered in destination countries, wider opportunity due to more people in developed countries leave low skilled jobs and the demand for migrant workers is also continually increase due to the higher population of aging-society.

Second, the social factors, the reason and push factors of migration of female migrant workers from Indramayu is to higher their social status in the family and society along with the improvement of their economic capabilities. The successful in destination countries and contribution to family economy will increase their status. The pull factor is migration will provide opportunity for the worker to enrich their experiences and skills, chance to continue their study and learn foreign languages. The chance to travelling abroad and attend special event at overseas is also a prestige to higher their status in Indramayu.

Third, the cultural factor, labor migration is heredity occupation in Indramayu. The demand and support of family to migration is high to female children in Indramayu. The perception to female children as asset to the family caused the increasing numbers of female migrant workers from Indramayu. The pull factors to work overseas in cultural term due to the working habit in destination countries, to be mentioned in Taiwan and Hong Kong. The working load is easier than the same work in Indonesia with higher salary. The people from destination countries are mostly welcome and friendly and respect the workers right.

\subsection{Recommendation}

For further research in this theme, the cultural push factors is important to be more elaborate particularly in the heredity occupation in Indramayu. Better understanding in this part may overcome the solution to human trafficking in Indramayu especially to its female migrant workers. The impact of migration that not only related to economic improvement which become the pull factors of female migrant workers from Indramayu would be utilitarian analysis for future migration studies.

Respondents to this research is needed to be expand and held in every region in Indramayu or West Java for broader input and understanding to proceses and motives of migration in Indramayu. Nowadays, working abroad is not only dominated by female migrant workers but also male workers. Therefore, the research for both is necessary to capture the more comprehensive labor migration reality in Indramayu and West Java.

\section{References}

ASEAN. (2010). ASEAN Statistical Yearbook. Jakarta, Indonesia: ASEAN Secretary.

Battistella, G. (2001). International Migration in Asia. Rome, Italy: Scalabrini

International Migration Institute

Djafar, Fariastuti and Mohd Khairul Hisyam Hassan. (2012). Dynamics of Push and Pull Factors of Migrant Workers in Developing Countries: The Case of Indonesian Workers in Malaysia. Journal of Economics and Behavioral Studies Vol. 4, No. 12, pp. 703711

Haas, De Hein. (2008). Migration and Development : A Theoretical Perspective. International Migration Institute, Oxford University.

ILO/UNI APRO.UNI MLC/ Aspek Indonesia, 2008. Workshop Papers on Migrant Workers. Medan, 20-21 September 2008

Laura A.King. (2010). Public Psychology : An Appreciative Perspective. Penerbit Salemba Humanika, Jakarta.

Mahmud Fadli Rakasima, dkk. (2011). 5 Years BNP2TKI : Serving with Love. BNP2TKI Jakarta (in Bahasa)

Muhammad Jumhur Hidayat. (2013). Optimalization the Role of Government in promoting, placement, and protection Migrant Workers with Soft System Methodology. Tesis Pasca Sarjana Sosiologi ,Universitas Indonesia.

Parker, M. (2014). The push and pull factors of economic migration. New African, , 14-17. Retrieved from http://search.proquest.com/ docview/1618841754? ?accountid=25704

Parkins Natasha C. (2010).Push and Pull Factors of Migration. American Review of Political Economy : 6-24.

Sridhar , Kala Seetharam and A. Venugopala Reddy and Pavan Srinath. (2013). Is it Push or Pull?: Recent Evidence from Migration into Bangalore, India. Springer Science+Business Media, pp 287-306

Skeldon, R. (2005). Globalization, Skilled Migration and Poverty Alleviation: Brain Drains in Context (working paper). Development Research Centre on Migration, Globalisation and Poverty University of Sussex.

Skeldon, R. (2008). International Migration as a Tool in Development Policy: A Passing Phase?. In: Population and Development Review, 34(1), pp. 1-18.

Southeast Asia Women's Caucus on the ASEAN (2013). Compliance with Women's Rights Standards: The Case of Migration of Domestic Workers from Indonesia and the Philippines in Brunei Darussalam. 
ISSN 2039-2117 (online)

ISSN 2039-9340 (print)
Mediterranean Journal of Social Sciences MCSER Publishing, Rome-Italy
Vol 6 No 5 S5

October 2015

\section{Online}

http://www.indramayukab.go.id/profile/49-kondisi-wilayah.html

www.republika.co.id/berita/nasional/jawa-barat-nasional/1408/17/nafyt0-kasus-perceraian-di-indramayu-tertinggi-seindonesia 